\title{
Beta-sheet hydrogen bonding patterns in cystine peptides
}

Timothy J. Cashman and Brian R. Linton*

Department of Chemistry, Bowdoin College, Brunswick, ME 004011

\section{Supporting Information}

General Procedures. Proton NMR were recorded on a Bruker 400 spectrometer. Proton chemical shifts are reported in ppm $(\delta)$ relative to internal tetramethylsilane (TMS, $\delta 0.0$ ppm), or with the solvent reference relative to TMS employed as an internal standard $\left(\mathrm{CDCl}_{3}, \delta 7.26 \mathrm{ppm}\right)$. Data are reported as follows: chemical shift (multiplicity [singlet $(\mathrm{s})$, doublet (d), triplet (t), quartet (q), multiplet (m)], coupling constant [Hz], integration). Carbon NMR spectra were recorded on a Bruker $400(100 \mathrm{MHz})$ spectrometer with complete proton decoupling. Carbon chemical shifts are reported in ppm $(\delta)$ relative to TMS with the respective solvent resonance as the internal standard $\left(\mathrm{CDCl}_{3}, \delta 77.23\right.$ ppm). Spectra for synthetic characterization were recorded at ambient temperature, while kinetic analyses were performed at $23^{\circ} \mathrm{C}$. Flash column chromatography was performed using Silica Gel $60 \AA$ (32-63 micron). ${ }^{1} \quad$ Synthetic yields are not optimized. High resolution mass spectra were acquired using a HiResMALDI Fourier transform mass spectrometer at Bowdoin College (Brunswick, ME). 


\section{Synthetic Procedures:}

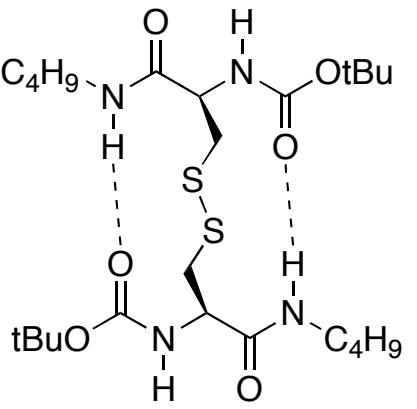

(Boc-Cys-NHBu) 2 (1). (Boc-Cys-OH $)_{2}(300 \mathrm{mg}, 0.68 \mathrm{mmol})$ was dissolved in $50 \mathrm{~mL}$ dichloromethane along with $\mathrm{HOBt}$ (208 mg, $1.36 \mathrm{mmol}$ ), EDCI (326 mg, $1.70 \mathrm{mmol}$ ), and butylamine (110 mg, $1.51 \mathrm{mmol})$. After stirring for 10 hours the solution was washed with $10 \% \mathrm{HCl}$, sat. $\mathrm{NaHCO}_{3}$, dried over $\mathrm{Na}_{2} \mathrm{SO}_{4}$ and evaporated to dryness under reduced pressure to yield $348 \mathrm{mg}$ (93\%) of a white solid. ${ }^{1} \mathrm{H}$ NMR $\delta 7.68$ (br, 2H), 5.63 (d, $J=$ $9.2 \mathrm{~Hz}, 2 \mathrm{H}), 4.79$ (br, 2H), 3.33-3.20 (br, 4H), 2.98-2.91 (m, 4H), $1.52(\mathrm{~m}, 4 \mathrm{H}), 1.47$ (s, $18 \mathrm{H}), 1.35(\mathrm{~m}, 4 \mathrm{H}), 0.91$ (t, $J=7.2 \mathrm{~Hz}, 6 \mathrm{H}) ;{ }^{13} \mathrm{C} \mathrm{NMR} \delta 170.2,156.0,80.1,54.9,47.5$, 39.5, 31.9, 28.5, 20.3, 13.9; HRMS (MALDI) calcd. for $\left[\mathrm{C}_{24} \mathrm{H}_{46} \mathrm{~N}_{4} \mathrm{O}_{6} \mathrm{~S}_{2} \mathrm{Na}\right]$ requires $m / z$ 573.27510, observed 573.27685.

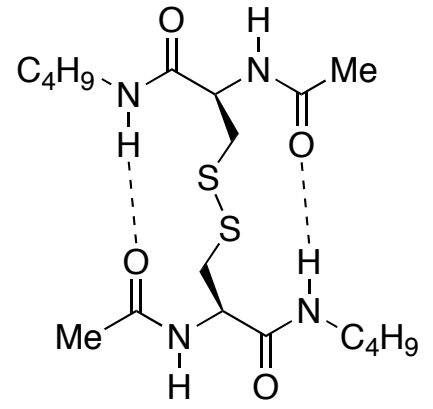

$(\text { Ac-Cys-NHBu })_{2}$ (2). (Boc-Cys-NHBu $)_{2} 1$ (100 mg, 0.18 mmol) was dissolved in $2 \mathrm{~mL}$ dichloromethane along with 2 $\mathrm{mL}$ trifluoroacetic acid. After stirring for two hours, all volatiles were removed under reduced pressure. The resulting paste was dissolved in $20 \mathrm{~mL}$ dichloromethane along with acetic anhydride $(50 \mathrm{mg}, 0.50 \mathrm{mmol})$, and

diisopropylethylamine $(60 \mathrm{mg}, 0.46 \mathrm{mmol})$. After stirring for 15 hours the solution was washed with $10 \% \mathrm{HCl}$, sat. $\mathrm{NaHCO}_{3}$, dried over $\mathrm{Na}_{2} \mathrm{SO}_{4}$ and evaporated to dryness under reduced pressure to yield $74 \mathrm{mg}(94 \%)$ of a white solid. ${ }^{1} \mathrm{H}$ NMR $\delta 8.14(\mathrm{br}, 2 \mathrm{H}), 6.68$ $(\mathrm{d}, J=9.2 \mathrm{~Hz}, 2 \mathrm{H}), 5.29$ (m, 2H), 3.31-3.20 (br, 4H), 3.00-2.86 (m, 4H), 2.05 (s, 6H), $1.54(\mathrm{~m}, 4 \mathrm{H}), 1.41(\mathrm{~m}, 4 \mathrm{H}), 0.93(\mathrm{t}, J=7.2 \mathrm{~Hz}, 6 \mathrm{H}) ;{ }^{13} \mathrm{C} \mathrm{NMR} \delta 170.5,170.2,53.7,46.9$, 39.5, 31.3, 23.6, 20.2, 13.9; HRMS (MALDI) calcd. for $\left[\mathrm{C}_{18} \mathrm{H}_{34} \mathrm{~N}_{4} \mathrm{O}_{4} \mathrm{~S}_{2} \mathrm{Na}\right]$ requires $m / z$ 457.19137, observed 457.19157. 
<smiles>CCCCCNC(=O)C(CSCc1ccccc1)NC(=O)OC(C)(C)C</smiles>

Boc-Cys(Bn)-NHBu (3). Boc-Cys-OH (500 mg, $1.61 \mathrm{mmol})$ was dissolved in $50 \mathrm{~mL}$ dichloromethane along with $\mathrm{HOBt}$ (250 mg, $1.63 \mathrm{mmol})$, EDCI (370 mg, $1.93 \mathrm{mmol})$, and butylamine (130 mg, $1.78 \mathrm{mmol})$. After stirring for 10 hours the solution was washed with $10 \% \mathrm{HCl}$, sat. $\mathrm{NaHCO}_{3}$, dried over $\mathrm{Na}_{2} \mathrm{SO}_{4}$ and evaporated to dryness under reduced pressure to yield $578 \mathrm{mg}(98 \%)$ of a pale oil that solidified over time to form white crystals. ${ }^{1} \mathrm{H}$ NMR $\delta 7.33-7.18(\mathrm{~m}, 5 \mathrm{H})$, 6.93 (br, 1H), 5.75 (br, 1H), 4.34 (br, 1H), 3.72 (s, 2H), 3.28-3.17 (m, 2H), 2.77 (d, $J=$ $6.4 \mathrm{~Hz}, 3 \mathrm{H}) 1.44(\mathrm{~m}, 11 \mathrm{H}), 0.89(\mathrm{t}, J=7.2 \mathrm{~Hz}, 3 \mathrm{H}) ;{ }^{13} \mathrm{C} \mathrm{NMR} \delta 170.7,155.5,137.9$, $128.9,128.4,127.0,79.8,53.4,39.2,36.3,33.9,31.4,28.2,19.9,13.6$; HRMS (MALDI) calcd. for $\left[\mathrm{C}_{19} \mathrm{H}_{30} \mathrm{~N}_{2} \mathrm{O}_{3} \mathrm{SNa}\right.$ ] requires $m / z$ 389.18693, observed 389.18804.

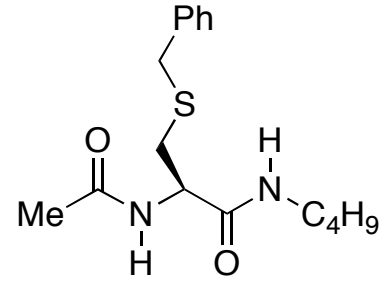
Ac-Cys(Bn)-NHBu (4). Boc-Cys-NHBu 3 (500 mg, 1.61 mmol) was dissolved in $50 \mathrm{~mL}$ dichloromethane along with HOBt (250 mg, $1.63 \mathrm{mmol})$, EDCI (370 mg, $1.93 \mathrm{mmol})$, and butylamine (130 mg, $1.78 \mathrm{mmol})$. After stirring for 10 hours the solution was washed with $10 \% \mathrm{HCl}$, sat. $\mathrm{NaHCO}_{3}$, dried over $\mathrm{Na}_{2} \mathrm{SO}_{4}$ and evaporated to dryness under reduced pressure to yield $578 \mathrm{mg}(98 \%)$ of a pale oil that solidified over time to form white crystals. ${ }^{1} \mathrm{H}$ NMR $\delta 7.60(\mathrm{~d}, J=8.4 \mathrm{~Hz}, 1 \mathrm{H}), 7.53(\mathrm{~m}, 1 \mathrm{H}), 7.31-7.20$ (m, 5H), $5.79(\mathrm{~m}, 1 \mathrm{H}), 3.27(\mathrm{~m}, 1 \mathrm{H}), 3.14(\mathrm{~m}, 1 \mathrm{H}), 2.75(\mathrm{~d}, J=7.2 \mathrm{~Hz}, 2 \mathrm{H}) 1.98(\mathrm{~s}, 3 \mathrm{H})$, $1.47(\mathrm{~m}, 1 \mathrm{H}), 1.33(\mathrm{~m}, 1 \mathrm{H}), 0.89(\mathrm{t}, J=7.2 \mathrm{~Hz}, 3 \mathrm{H}) ;{ }^{13} \mathrm{C} \mathrm{NMR} \delta 170.8,1705,138.1$, 129.0, 128.5, 127.0, 52.5, 39.3, 36.3, 33.8, 31.3, 22.9, 20.0, 13.7; HRMS (MALDI) calcd. for $\left[\mathrm{C}_{16} \mathrm{H}_{24} \mathrm{~N}_{2} \mathrm{O}_{2} \mathrm{SNa}\right.$ ] requires $m / z$ 331.14507, observed 331.14649.

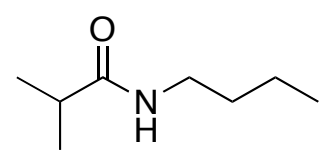

N-butyl-2-methylpropanamide (5). ${ }^{2}$ Isobutyric acid (200 mg, 2.27 mmol) was dissolved in $20 \mathrm{~mL}$ dichloromethane along with EDCI (480 mg, $2.50 \mathrm{mmol})$ and butylamine (182 mg, $2.50 \mathrm{mmol})$. After stirring for 5 hours, the solution was washed with $10 \% \mathrm{HCl}$, sat $\mathrm{NaHCO}_{3}$, dried over $\mathrm{Na}_{2} \mathrm{SO}_{4}$ and evaporated to dryness under reduced pressure to yield $178 \mathrm{mg}(55 \%)$ of a clear oil. ${ }^{1} \mathrm{H}$ NMR $\delta 5.91$ (br, $\left.1 \mathrm{H}\right), 3.23$ (q, $\left.J=6.6 \mathrm{~Hz}, 2 \mathrm{H}\right), 2.37$ (m, 1H), $1.49(\mathrm{~m}, 2 \mathrm{H})$, $1.34(\mathrm{~m}, 2 \mathrm{H}), 1.14(\mathrm{~d}, J=6.9 \mathrm{~Hz}, 6 \mathrm{H}), 0.92(\mathrm{t}, J=7.3 \mathrm{~Hz}, 3 \mathrm{H}) ;{ }^{13} \mathrm{C} \mathrm{NMR} \delta 177.2,39.2$, 
35.7, 31.9, 20.2, 19.8, 13.9; MS (EI): 143 (M+, 43), 128 (28), 114 (14), 101(59), 100 (60), 88 (24), 73 (31), 72 (68), 71 (100), 57 (100).

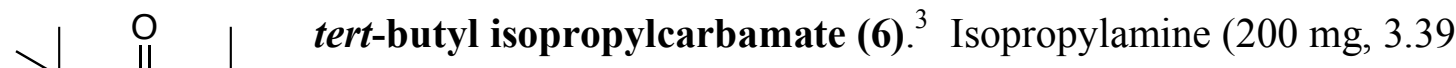
mmol) was dissolved in $10 \mathrm{~mL}$ acetonitrile. Tetrabutylammonium hydroxide (614 mg, $3.39 \mathrm{mmol}$ ) was added as a suspension and stirred for one hour. Ditert-butyl dicarbonate (900 mg, $4.12 \mathrm{mmol}$ ) was added and the solution was stirred for two days. The solvent was removed in vacuo and the residue partitioned between $\mathrm{Et}_{2} \mathrm{O}$ and $\mathrm{H}_{2} \mathrm{O}$. The water layer was washed twice $\mathrm{Et}_{2} \mathrm{O}$ and the combined organic fractions were dried over $\mathrm{Na}_{2} \mathrm{SO}_{4}$ and evaporated to dryness under reduced pressure to yield 426 mg (79\%) of a white solid. ${ }^{1} \mathrm{H}$ NMR $\delta 4.76$ (br, 1H), 3.76 (br, 1H), 1.44 (s, 9H), 1.13 (d, $J=6.4 \mathrm{~Hz}, 6 \mathrm{H}) ;{ }^{13} \mathrm{C}$ NMR $\delta$ 155.1, 78.5, 42.3, 28.3, 22.9; MS (EI): 159 (M+, 1), 144 (20), 104 (27), 88 (11), 59 (41), 57 (100).

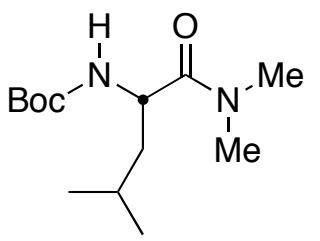

Boc-Leu-NMe (9). Boc-Leu-OH (2.0 g, $8.02 \mathrm{mmol})$ was dissolved $100 \mathrm{~mL}$ dichloromethane along with HOBt (610 mg, $3.99 \mathrm{mmol})$, and EDCI (1.85 g, $9.65 \mathrm{mmol})$. To this was added solid diethylamine hydrochloride $(785 \mathrm{mg}, 9.66 \mathrm{mmol})$ and diisopropylethylamine $(1.035 \mathrm{~g}, 8.02 \mathrm{mmol})$ and the mixture was stirred overnight. For best results additional diethylamine hydrochloride $(100 \mathrm{mg})$ and diisopropylethylamine (100 mg) were added and the solution was stirred for an additional four hours. The solution was washed with $10 \% \mathrm{HCl}$, sat. $\mathrm{NaHCO}_{3}$, dried over $\mathrm{Na}_{2} \mathrm{SO}_{4}$ and evaporated to dryness under reduced pressure to yield a clear oil (1.79 g, 86\%). ${ }^{1} \mathrm{H}$ NMR $\delta 5.31$ (br, 1H), 4.66 (m, 1H), 3.09 (s, 3H), 2.96 (s, 3H), 1.73 (br, 1H), 1.43 (m\&s, 11H), 1.00 (d, J= $6.4 \mathrm{~Hz}, 1 \mathrm{H}), 0.93(\mathrm{~d}, J=6.7 \mathrm{~Hz}, 1 \mathrm{H}) ;{ }^{13} \mathrm{C} \mathrm{NMR} \delta 173.1,155.8,79.5,53.6,48.7,42.8$, 37.1, 35.8, 28.5, 28.4, 24.7, 23.6, 21.9; HRMS (MALDI) calcd. for $\left[\mathrm{C}_{13} \mathrm{H}_{26} \mathrm{~N}_{2} \mathrm{O}_{3} \mathrm{Na}\right]$ requires $m / z 281.18356$, observed 281.18416 .<smiles>CCCSCC(NC(=O)OCC)C(=O)N[C@@H](CC(C)C)C(=O)N(C)C</smiles>

Fmoc-Cys(Trt)-Leu-NMe (10). Boc-Leu-NMe 7 (500 $\mathrm{mg}, 1.94 \mathrm{mmol}$ ) was dissolved in $1 \mathrm{~mL}$ dichloromethane to which was added trifluoroacetic acid $(1 \mathrm{~mL})$. After stirring 
for one hour all volatiles were removed under reduced pressure. The resulting crude paste was added to a solution containing Fmoc-Cys(Trt)-OH (1077 mg, $1.84 \mathrm{mmol})$, HOBt (281 mg, $1.84 \mathrm{mmol})$, EDCI (388 mg, $2.02 \mathrm{mmol})$ that had previously been allowed to stir for twenty minutes. Diisopropylethylamine (550 mg, $4.26 \mathrm{mmol}$ ) was added and the solution was stirred for sixteen hours. The solution was washed with $10 \%$ $\mathrm{HCl}$, sat. $\mathrm{NaHCO}_{3}$, dried over $\mathrm{Na}_{2} \mathrm{SO}_{4}$ and evaporated to dryness under reduced pressure to yield $1.545 \mathrm{~g}$ of a yellow foam. The crude peptide was purified using flash chromatography (silica, 1-5\% methanol:dichloromethane) to yield a yellow solid (1.03 g, 77\%). ${ }^{1} \mathrm{H}$ NMR $\delta 7.72(\mathrm{t}, J=7.7 \mathrm{~Hz}, 2 \mathrm{H}), 7.56(\mathrm{~m}, 2 \mathrm{H}), 7.40(\mathrm{~m}, 8 \mathrm{H}), 7.26(\mathrm{~m}, 8 \mathrm{H})$, $7.19(\mathrm{~m}, 3 \mathrm{H}), 6.76$ (br-d, $J=7.8 \mathrm{~Hz}, 6 \mathrm{H}), 5.18$ (d, $J=8.0 \mathrm{~Hz}, 6 \mathrm{H}), 4.91$ (m, 1H), 4.34 (m, 2H), $4.19(\mathrm{~m}, 1 \mathrm{H}), 3.90(\mathrm{~m}, 1 \mathrm{H}), 3.02(\mathrm{~s}, 3 \mathrm{H}), 2.89(\mathrm{~s}, 3 \mathrm{H}), 2.59(\mathrm{~m}, 1 \mathrm{H}), 2.55(\mathrm{~m}, 1 \mathrm{H})$, $1.61(\mathrm{br}, 1 \mathrm{H}), 1.49-1.39(\mathrm{~m}, 2 \mathrm{H}), 0.93(\mathrm{~d}, J=5.9 \mathrm{~Hz}, 3 \mathrm{H}), 0.84(\mathrm{~d}, J=6.5 \mathrm{~Hz}, 3 \mathrm{H}) ;{ }^{13} \mathrm{C}$ NMR $\delta 171.7,166.7,155.6,144.4,141.1,129.5,127.9,127.6,127.0,126.7,125.1$, 119.8, 66.9, 53.5, 47.3, 47.0, 42.1, 36.9, 35.7, 34.3, 28.3, 24.4, 23.4, 22.0; HRMS (MALDI) calcd. for $\left[\mathrm{C}_{45} \mathrm{H}_{47} \mathrm{~N}_{3} \mathrm{O}_{4} \mathrm{SNa}\right]$ requires $m / z$ 748.31795, observed 748.31834 .

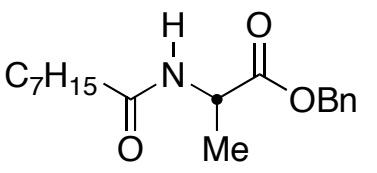

Oct-Ala-OBn (11). Octanoyl chloride (400 mg, $2.46 \mathrm{mmol}$ ) was dissolved in $50 \mathrm{~mL}$ dichloromethane. To this was added H-Ala$\mathrm{OBn} \cdot \mathrm{HCl}(583 \mathrm{mg}, 2.70 \mathrm{mmol})$ and triethylamine $(600 \mathrm{mg}, 5.94$ mmol). After stirring for sixteen hours the solution was washed with $10 \% \mathrm{HCl}$, sat. $\mathrm{NaHCO}_{3}$, dried over $\mathrm{Na}_{2} \mathrm{SO}_{4}$ and evaporated to dryness under reduced pressure to yield $735 \mathrm{mg}(98 \%)$ of a white solid. ${ }^{1} \mathrm{H}$ NMR $\delta 7.36(\mathrm{~m}, 5 \mathrm{H}), 6.02(\mathrm{~d}, J=6.8 \mathrm{~Hz}, 1 \mathrm{H}), 5.20$ $(\mathrm{d}, J=12.3 \mathrm{~Hz}, 1 \mathrm{H}), 5.16(\mathrm{~d}, J=12.3 \mathrm{~Hz}, 1 \mathrm{H}), 4.66(\mathrm{~m}, 1 \mathrm{H}), 2.20(\mathrm{t}, J=7.4 \mathrm{~Hz}, 1 \mathrm{H})$, $1.61(\mathrm{~m}, 2 \mathrm{H}), 1.41(\mathrm{~d}, J=5.5 \mathrm{~Hz}, 1 \mathrm{H}), 1.28(\mathrm{~m}, 8 \mathrm{H}), 0.87(\mathrm{t}, J=6.7 \mathrm{~Hz}, 1 \mathrm{H})) ;{ }^{13} \mathrm{C} \mathrm{NMR}$ $\delta 173.0,172.9,135.4,128.5,128.3,128.0,66.9,47.9,36.3,31.6,29.2,29.0,25.6,22.6$, 18.2, 14.0; HRMS (MALDI) calcd. for $\left[\mathrm{C}_{18} \mathrm{H}_{27} \mathrm{NO}_{3} \mathrm{Na}\right]$ requires $m / z$ 328.18831, observed 328.18854 .

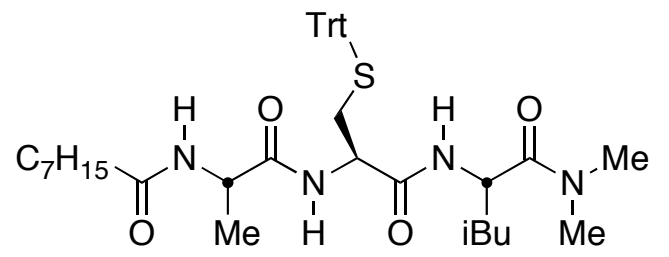
Oct-Ala-Cys(Trt)-Leu-NMe (7). FmocCys(Trt)-Leu-NMe 10 (238 mg, 0.33 mmol) was dissolved in acetonitrile $(2 \mathrm{~mL})$. 
Diethylamine $(2 \mathrm{~mL})$ was added and the solution was stirred for two hours. After all volatiles were removed under vacuum, more acetonitrile was added and removed under vacuum to facilitate the azeotropic removal of additional diethylamine. In a separate flask, Oct-Ala-OBn 11 (100 mg, $0.33 \mathrm{mmol}$ ) was dissolved in $10 \mathrm{~mL}$ methanol, and catalytic palladium on carbon $(10 \mathrm{mg})$ was added. The mixture was placed under an atmosphere of hydrogen for four hours. The catalyst was removed by filtration through Celite, and the solution was concentrated to dryness under vacuum. The crude oil was dissolved in dichloromethane (20 mL) along with HOBt (50 mg, $0.33 \mathrm{mmol})$, and EDCI (75 mg, $0.39 \mathrm{mmol}$ ) and stirred for fifteen minutes. To this was added the deprotected $\mathrm{H}-$ Cys(Trt)-Leu- $\mathrm{NMe}_{2}$ dissolved in $10 \mathrm{ml}$ dichloromethane and subsequently diisopropylethylamine $(93 \mathrm{mg}, 0.72 \mathrm{mmol})$. After stirring for 12 hours the solution was washed with $10 \% \mathrm{HCl}$, sat. $\mathrm{NaHCO}_{3}$, dried over $\mathrm{Na}_{2} \mathrm{SO}_{4}$ and evaporated to dryness under reduced pressure to yield $259 \mathrm{mg}$ of a yellow solid. Pure material (109 mg) was obtained using flash chromatography (silica, 1-5\% methanol:dichloromethane). ${ }^{1} \mathrm{H}$ NMR $\delta 7.41$ $(\mathrm{m}, 6 \mathrm{H}), 7.30(\mathrm{~m}, 6 \mathrm{H}), 7.22(\mathrm{t}, J=7.2,3 \mathrm{H}), 6.73(\mathrm{~d}, J=8.6,1 \mathrm{H}), 6.22(\mathrm{~d}, J=7.7,1 \mathrm{H})$, $6.15(\mathrm{~d}, J=7.3,1 \mathrm{H}), 4.87(\mathrm{~m}, 1 \mathrm{H}), 4.40(\mathrm{~m}, 1 \mathrm{H}), 4.10(\mathrm{~m}, 1 \mathrm{H}), 3.03(\mathrm{~s}, 3 \mathrm{H}), 2.91$ (s, 3H), $2.79(\mathrm{dd}, J=13.1,7.4,1 \mathrm{H}), 2.51(\mathrm{dd}, J=13.1,5.0,1 \mathrm{H}), 2.16(\mathrm{t}, J=7.7,2 \mathrm{H}), 1.59$ (br, 3H), 1.47-1.38 (m, 2H), 1.31 (d, $J=7.0,3 \mathrm{H}), 1.26$ (br, 8H), 0.94 (d, $J=6.4,1 \mathrm{H})$, 1.87 (m, 6H); ${ }^{13} \mathrm{C}$ NMR $\delta$ 173.1, 172.4, 171.8, 169.2, 144.5, 129.7, 128.3, 127.1, 67.3, $52.5,48.6,47.6,42.5,37.2,36.7,35.9,33.5,31.9,29.4,29.2,25.8,24.8,23.6,22.8,22.1$, 18.9, 14.3; HRMS (MALDI) calcd. for $\left[\mathrm{C}_{41} \mathrm{H}_{56} \mathrm{~N}_{4} \mathrm{O}_{4} \mathrm{SNa}\right]$ requires $m / z$ 723.39145, observed 723.38998 .

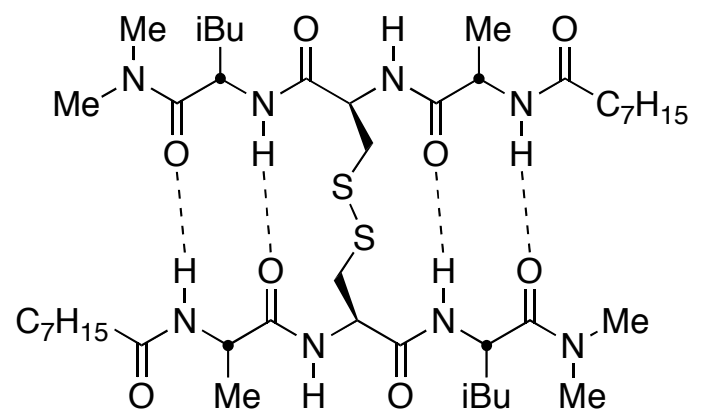

(Oct-Ala-Cys-Leu-NMe $)_{2}$ (8). Oct-AlaCys(Trt)-Leu-NMe 5 (43 mg, $0.061 \mathrm{mmol})$ was dissolved in $10 \mathrm{~mL}$ dichloromethane. To this was added a solution of iodine (19 $\mathrm{mg}$, $0.075 \mathrm{mmol}$ ) dissolved in $5 \mathrm{~mL}$ dichloromethane. ${ }^{4}$ The reaction mixture was stirred for one hour, at which point the solvents were removed under reduced pressure. The crude peptide was purified using silica chromatography (1-5\% $\left.\mathrm{MeOH}: \mathrm{CH}_{2} \mathrm{Cl}_{2}\right)$ to 
yield a white powder $(20 \mathrm{mg}, 71 \%) .{ }^{1} \mathrm{H}$ NMR $\delta 8.61(\mathrm{~d}, J=8.6,2 \mathrm{H}$, Leu-NH), $7.62(\mathrm{~d}$, $J=8.2,2 \mathrm{H}$, Ala-NH), 6.92 (d, $J=9.3,2 \mathrm{H}$, Cys-NH), 5.64 (m, 2H, Cys- $\alpha), 5.00$ (m, 2H, Leu- $\alpha$ ), 4.70 (m, 2H, Ala- $\alpha$ ), 3.12 (s, 6H, $\mathrm{NMe}_{2}$ ), 2.96 (s, 6H, NMe $), 2.84$ (m, 4H, Cysß), $2.30\left(\mathrm{t}, J=7.4,4 \mathrm{H}, \mathrm{CH}_{2} \mathrm{CO}\right), 1.71(\mathrm{~m}, 2 \mathrm{H}), 1.61(\mathrm{~m}, 6 \mathrm{H}), 1.48\left(\mathrm{~m}, 2 \mathrm{H}, \mathrm{Leu}-\mathrm{CH}_{2}\right)$, $1.36\left(\mathrm{~d}, J=6.7,6 \mathrm{H}\right.$, Ala- $\left.\mathrm{CH}_{3}\right), 1.25\left(\mathrm{~m}, 16 \mathrm{H}\right.$, octyl- $\left.\mathrm{CH}_{2}\right), 1.01$ (d, $\left.J=6.4,6 \mathrm{H}, \mathrm{Leu}-\mathrm{CH}_{3}\right)$, $0.93\left(\mathrm{~d}, J=6.5,6 \mathrm{H}\right.$, Leu- $\left.\mathrm{CH}_{3}\right), 0.86\left(\mathrm{~d}, J=6.7,6 \mathrm{H}\right.$, octyl- $\left.\mathrm{CH}_{3}\right) ;{ }^{13} \mathrm{C}$ NMR $\delta 173.6$, 172.5, 170.0, 52.8, 48.7, 47.6, 42.8, 37.4, 36.4, 36.0, 31.9, 29.5, 29.3, 26.0, 24.9, 23.5, 22.8, 22.2, 18.9, 14.3; HRMS (MALDI) calcd. for $\left[\mathrm{C}_{44} \mathrm{H}_{82} \mathrm{~N}_{8} \mathrm{O}_{8} \mathrm{~S}_{2} \mathrm{Na}\right]$ requires $m / z$ 937.55892, observed 937.55963. 
General procedure for determination of chemical shift change with concentration.

An initial NMR spectra was acquired with $400 \mu \mathrm{L}$ of an analyte solution of

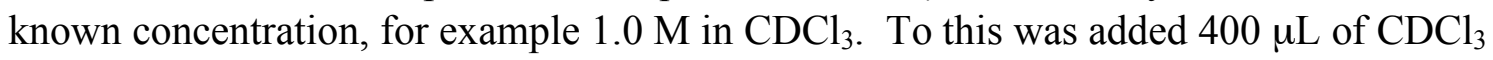
to achieve a concentration of $500 \mathrm{mM}$. Addition of another $800 \mu \mathrm{L}$ of $\mathrm{CDCl}_{3}$ achieved a concentration of $250 \mathrm{mM}$. Transfer of $160 \mu \mathrm{L}$ to a new NMR tube and dilution with 240 $\mu \mathrm{L} \mathrm{CDCl}{ }_{3}$ resulted in a $100 \mathrm{mM}$ solution. Similar dilution patterns were repeated through concentrations of 50, 25, 10, 5, 2.5, 1, 0.5, $0.25 \mathrm{mM}$, until the NMR signals were no longer visible.

\section{General procedure for determination of chemical shift change with added solvent.}

Substrate was dissolved in both $\mathrm{C}_{6} \mathrm{D}_{6}$ and DMSO- $\mathrm{d}_{6}$ to a known concentration in this case $2.0 \mathrm{mM}$. After recording the NMR spectra of $450 \mu \mathrm{L}$ of the $\mathrm{C}_{6} \mathrm{D}_{6}$ solution, aliquots of the DMSO solution were added to the benzene NMR tube according to the amounts listed in Table S1.

Table S1. Conditions used in monitoring changes in NMR chemical shift in $\mathrm{C}_{6} \mathrm{D}_{6} / \mathrm{DMSO}-\mathrm{d}_{6}$.

\begin{tabular}{|c|c|c|c|}
\hline DMSO added & Total Added & Total Volume & \% DMSO \\
\hline 5 & 5 & 455 & 1 \\
\hline 5 & 10 & 460 & 2 \\
\hline 14 & 24 & 474 & 5 \\
\hline 26 & 50 & 500 & 10 \\
\hline 65 & 115 & 565 & 20 \\
\hline 80 & 195 & 645 & 30 \\
\hline 105 & 300 & 750 & 40 \\
\hline 150 & 450 & 900 & 50 \\
\hline
\end{tabular}

Figure S1. Dependence of NMR chemical shifts on percentage of DMSO- $\mathrm{d}_{6}$ in $\mathrm{C}_{6} \mathrm{D}_{6}$.

a) Boc-cystine dimer $\mathbf{1}(\mathrm{Boc}-\mathrm{NH}=\mathbf{\square} ; \mathrm{NHBu}=\bullet$ ) and Boc-cystine monomer $\mathbf{3}(\mathrm{Boc}-\mathrm{NH}=\diamond ; \mathrm{NHBu}=\mathbf{\Delta})$.

b) Acetyl-cystine dimer $2(\mathrm{Ac}-\mathrm{NH}=\square ; \mathrm{NHBu}=\mathrm{O})$ and acetyl-cystine monomer $4(\mathrm{Ac}-\mathrm{NH}=\diamond ; \mathrm{NHBu}=\triangle)$.
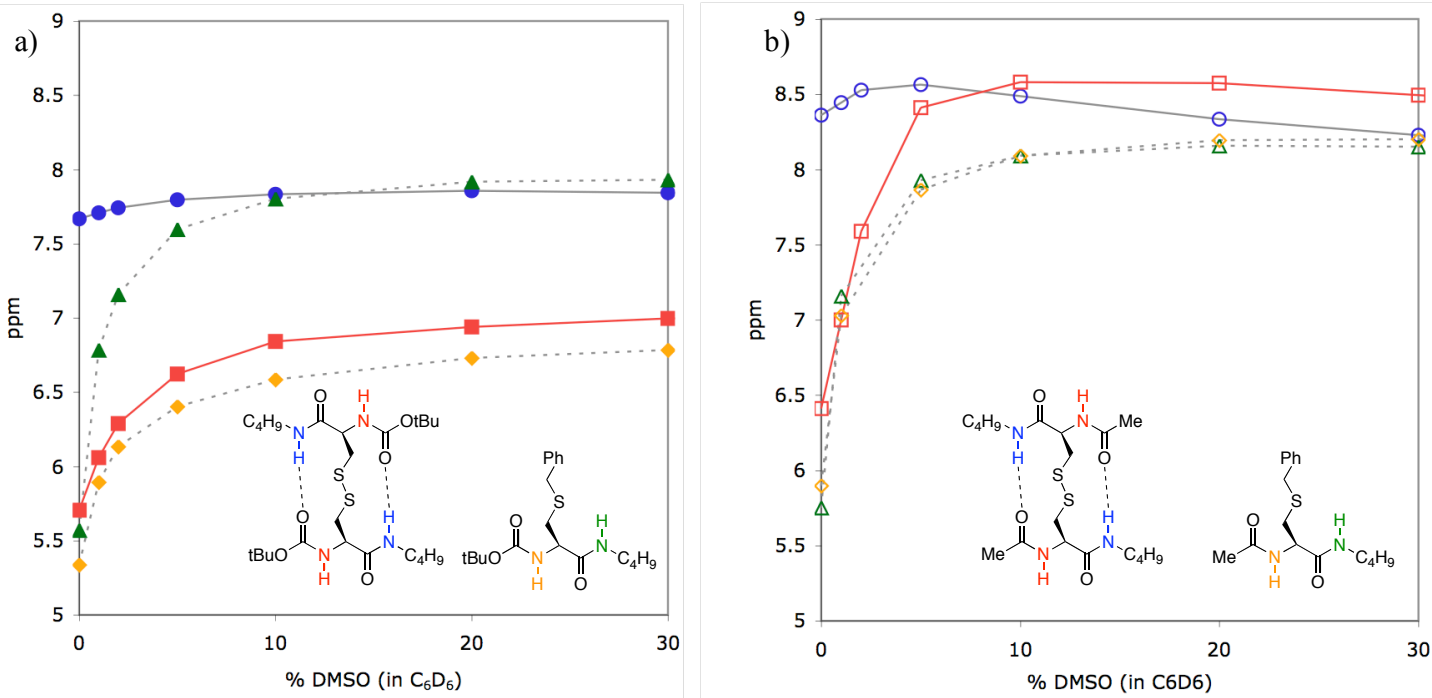
Figure S2. Dependence of NMR chemical shifts on concentration.

Closed symbols refer to tripeptide dimer 8 (Ala-NH $=\mathbf{\Delta} ; \mathrm{Cys}-\mathrm{NH}=\mathbf{\square} ; \mathrm{Leu}-\mathrm{NH}=\bullet$ ).

Open symbols refer to tripeptide monomer 7 (Ala-NH $=\triangle$; Cys-NH $=\square$; Leu-NH $=O$ ).

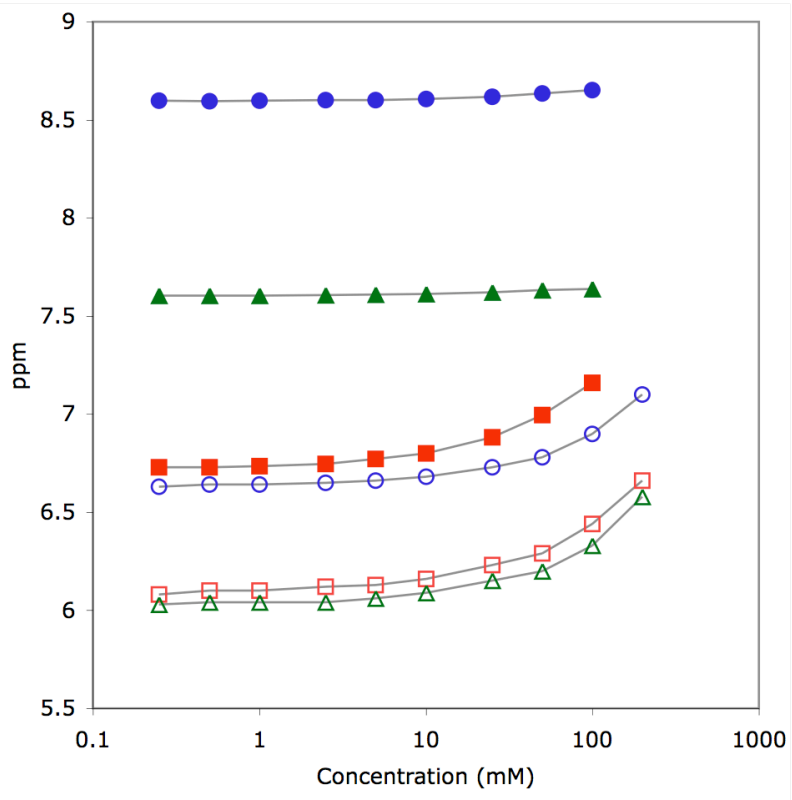

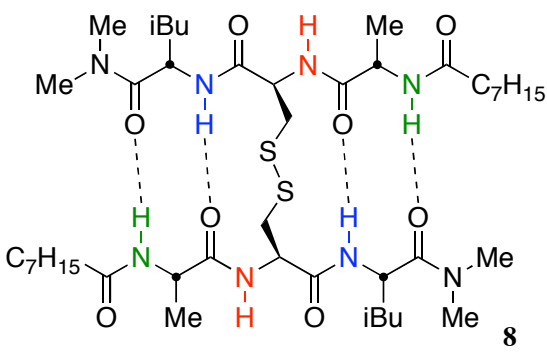

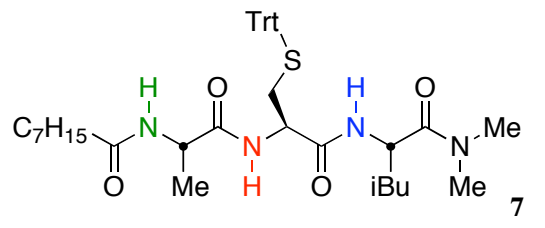

Table S1. Total chemical shift for tripeptides $\mathbf{7}$ and $\mathbf{8}$ over various concentrations.

\begin{tabular}{cccc}
\hline Substrate & Proton & $\begin{array}{c}\text { Total shift }(\mathrm{ppm}) \\
100-0.25 \mathrm{mM}\end{array}$ & $\begin{array}{c}\text { Total shift }(\mathrm{ppm}) \\
200-0.25 \mathrm{mM}\end{array}$ \\
\hline 8 & Leu-NH & 0.05 & \\
8 & Ala-NH & 0.03 & \\
8 & Cys-NH & 0.43 & 0.47 \\
7 & Leu-NH & 0.27 & 0.55 \\
7 & Ala-NH & 0.30 & 0.58 \\
7 & Cys-NH & 0.36 & \\
\hline
\end{tabular}


Figure S3. Dependence of NMR chemical shifts on percentage of DMSO- $d_{6}$ in $\mathrm{C}_{6} \mathrm{D}_{6}$.

a) Closed symbols refer to tripeptide dimer 8 (Ala-NH $=\Delta$; Cys-NH $=\square$; Leu-NH $=\bullet$ ).

b) Open symbols refer to tripeptide monomer 7 (Ala-NH $=\triangle$; Cys-NH $=\square$; Leu-NH $=\mathrm{O}$ ).
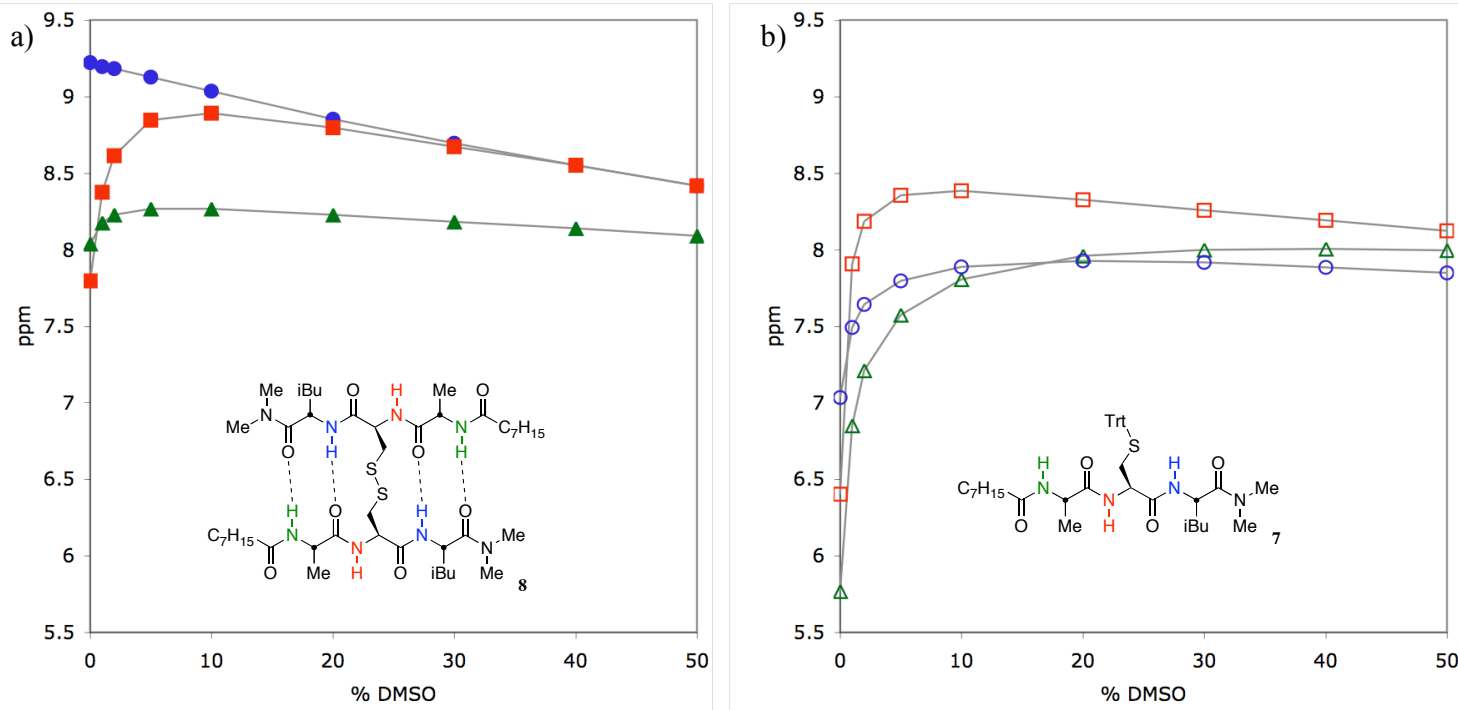

Figure S4. Comparison for alpha protons for peptides $\mathbf{7}$ (bottom) and $\mathbf{8}$ (top) in $\mathrm{CDCl}_{3}$.

a) Closed symbols refer to tripeptide dimer 8 (Ala-NH $=\mathbf{\Delta} ;$ Cys-NH $=\mathbf{a} ;$ Leu-NH $=\bullet$ ).

b) Open symbols refer to tripeptide monomer 7 (Ala-NH $=\triangle$; Cys-NH $=\square$; Leu-NH $=O$ ).
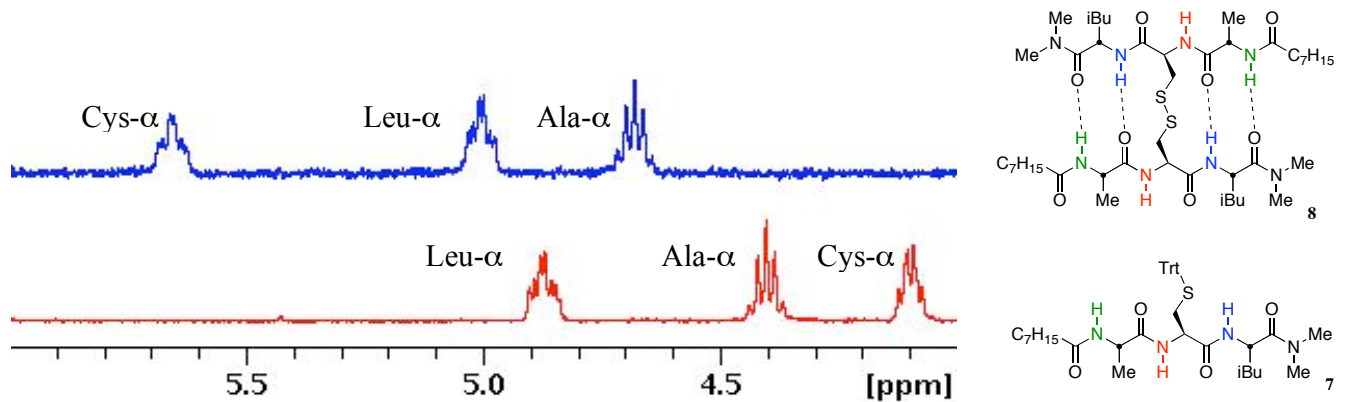

$\Delta$ ppm (7-8): Leu=0.14 ppm; Ala $=0.3$ ppm; Cys $=1.5$ ppm

Figure S5. Comparison for $\mathrm{NH}$ protons for peptides $\mathbf{7}$ (bottom) and $\mathbf{8}$ (top) in $\mathrm{CDCl}_{3}$.

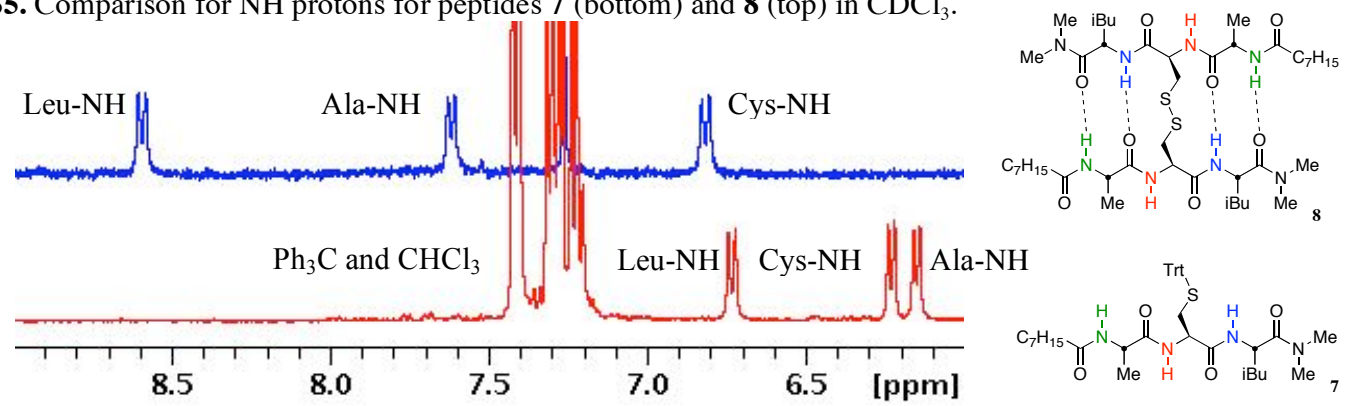

$\Delta$ ppm (7-8): Leu=1.9 ppm; Ala=1.5 ppm; Cys=0.7 ppm 


\section{General procedure for $H / D$ exchange:}

An initial NMR spectrum was acquired with $450 \mu \mathrm{L}$ of an analyte solution with a concentration of $11.11 \mathrm{mM}$ in $\mathrm{CDCl}_{3}$. To this was added $50 \mu \mathrm{L}$ of $\mathrm{CD}_{3} \mathrm{OD}$ marking time $=0$. This procedure resulted in a final substrate concentration of $10 \mathrm{mM}$, which was well below the concentrations where any evidence of aggregation has been observed. The added methanol created a 10\% methanol:chloroform solution, with the final methanol concentration of $2.47 \mathrm{M}$, which ensured pseudo-first-order kinetics. For a typical experiment, spectra were acquired at 2, 4, 7, 10 minutes, then every 5 minutes through 100 minutes, at 120, 150 and 200 minutes, and then every 100 minutes thereafter until the disappearance of the proton signal into the baseline. If signals persisted beyond 2500 minutes, spectra were acquired every 1500 minutes ( $25 \mathrm{hrs}$ ). To minimize variability, a constant baseline correction was applied, and integration ranges for exchanging protons were user-defined and self-consistent within each experiment. A distinct non-exchanging signal was used as an internal integration reference. Pseudo-first-order kinetic analyses were determined from the fit of a non-linear least squares fit to the graph of $A_{t}=$ $\mathrm{A}_{\mathrm{o}}{ }^{*} \exp (-\mathrm{kt})$. Analyses are the average of at least two runs acquired on non-successive days, with different solvents to ensure reproducibility. Rather than estimate the values at extended time, curve fits were performed using data that was $<90 \%$ exchanged. The yintercept is taken as the calculated value at time zero, and this value is used to normalize the final data to a range from $100-0 \%$ hydrogen remaining. Rates were found to be dependent on solvent and substrate purity. Fresh ampules of methanol- $\mathrm{d}_{4}$ were opened weekly, and fresh chloroform-d stored over activated molecular sieves was prepared at least monthly, otherwise artificial increases in the H/D exchange rate were observed.

(1) Still, W. C.; Kahn, M.; Mitra, J. J. Org. Chem. 1978, 43, 2923-2924.

(2) Steffel, L. R.; Cashman, T. J.; Reutershan, M. H.; Linton B. R. J. Am. Chem. Soc. 2007, 129, accepted for publication.

(3) Khalil, E. M.; Subasinghe, N. L.; Johnson, R. L. Tetrahedron Lett. 1996, 37, 34413444.

(4) Sieber, P.; Kamber, B.; Riniker, B.; Rittel, W. Helv. Chim. Acta 1980, 63, 2358. 


\section{$(\text { Boc-Cys-NHBu })_{2}(1)$}
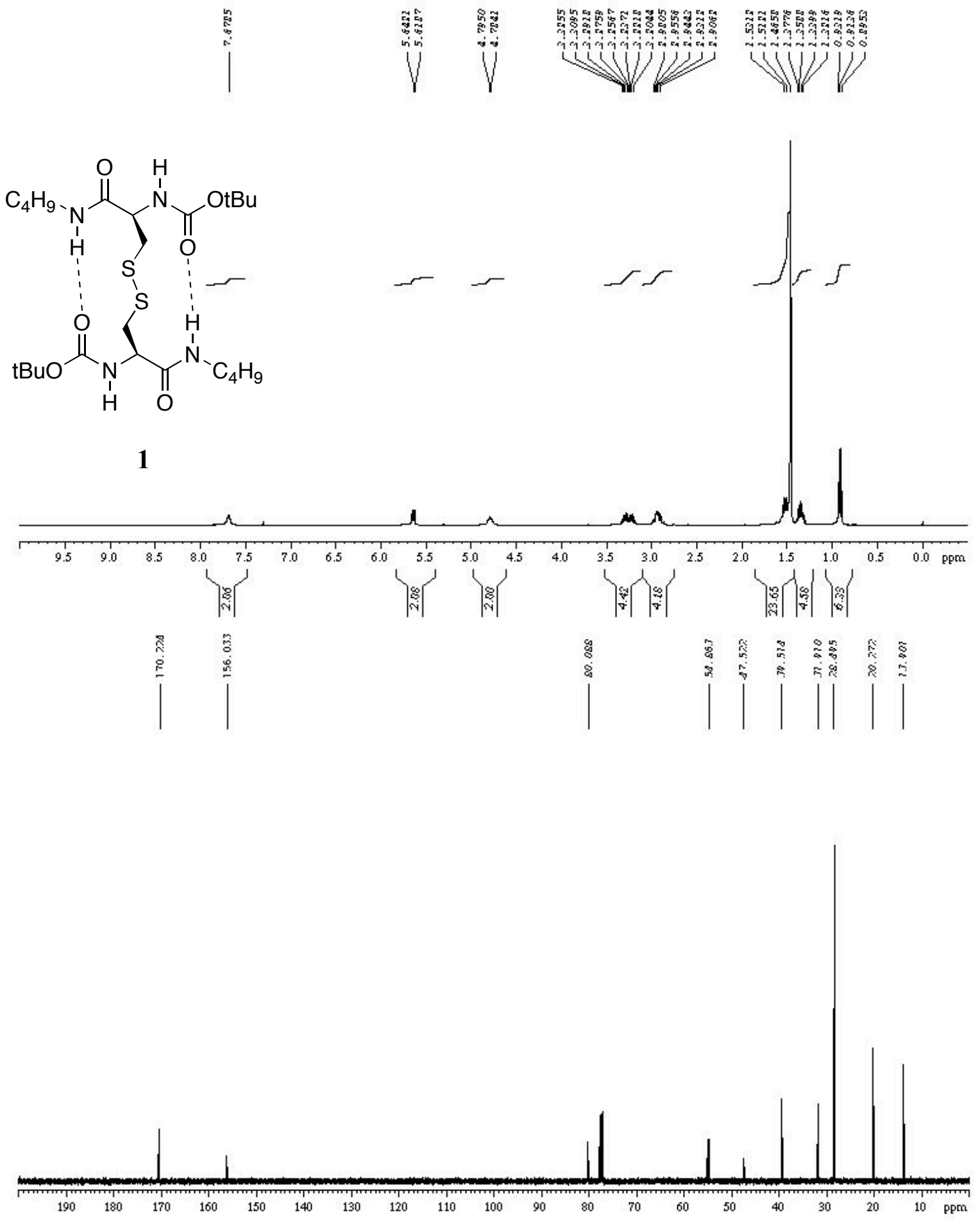
$(\mathrm{Ac}-\mathrm{Cys}-\mathrm{NHBu})_{2}(2)$
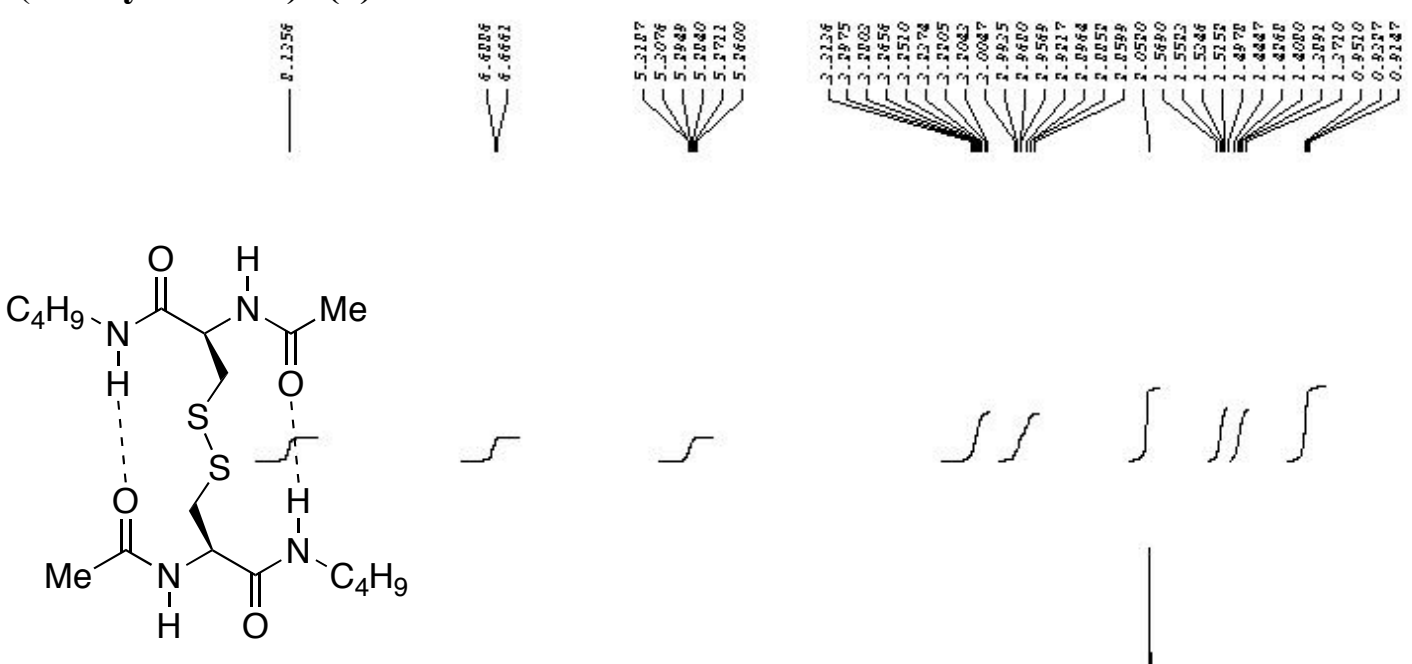

2
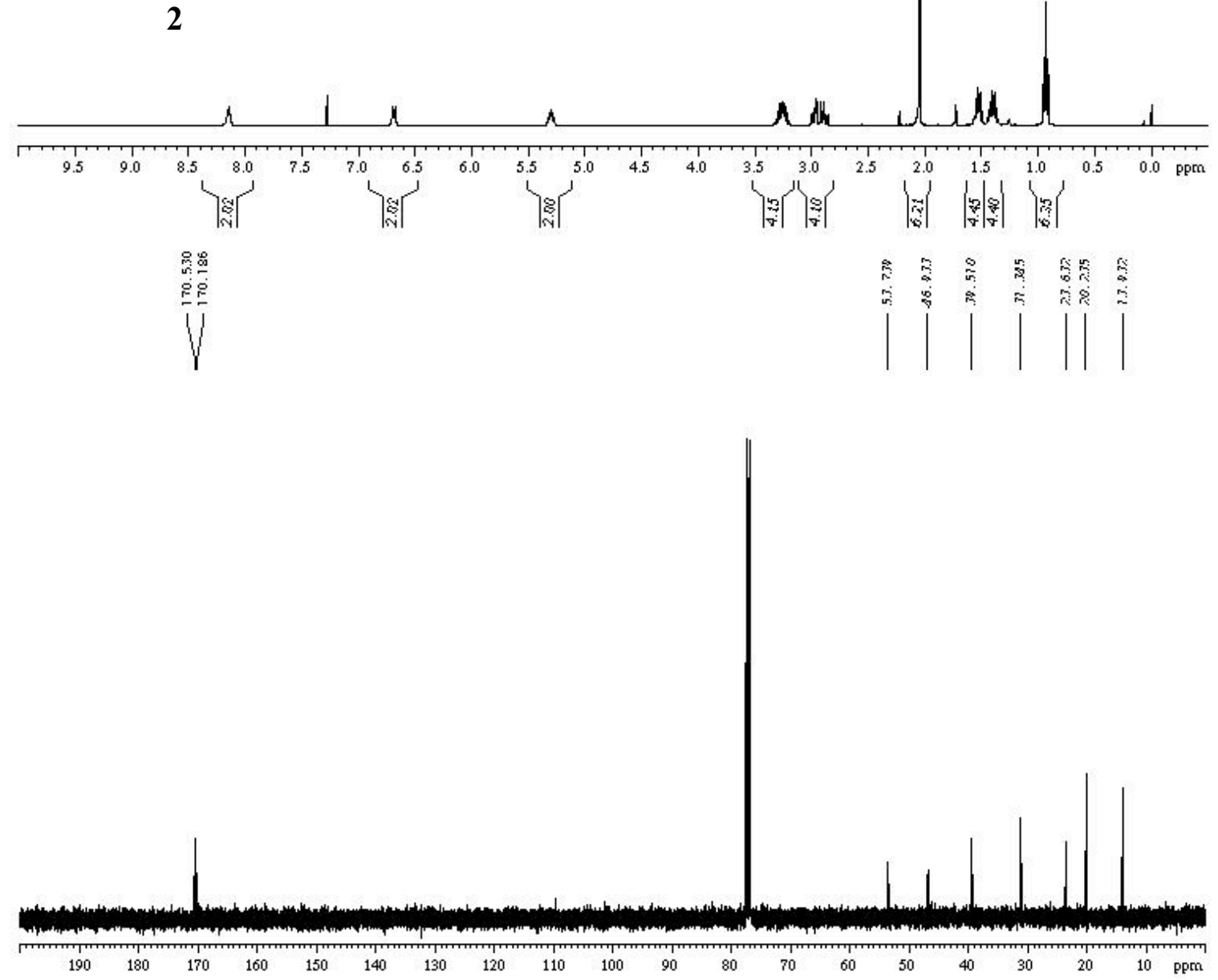


\section{Boc-Cys(Bn)-NHBu (3)}
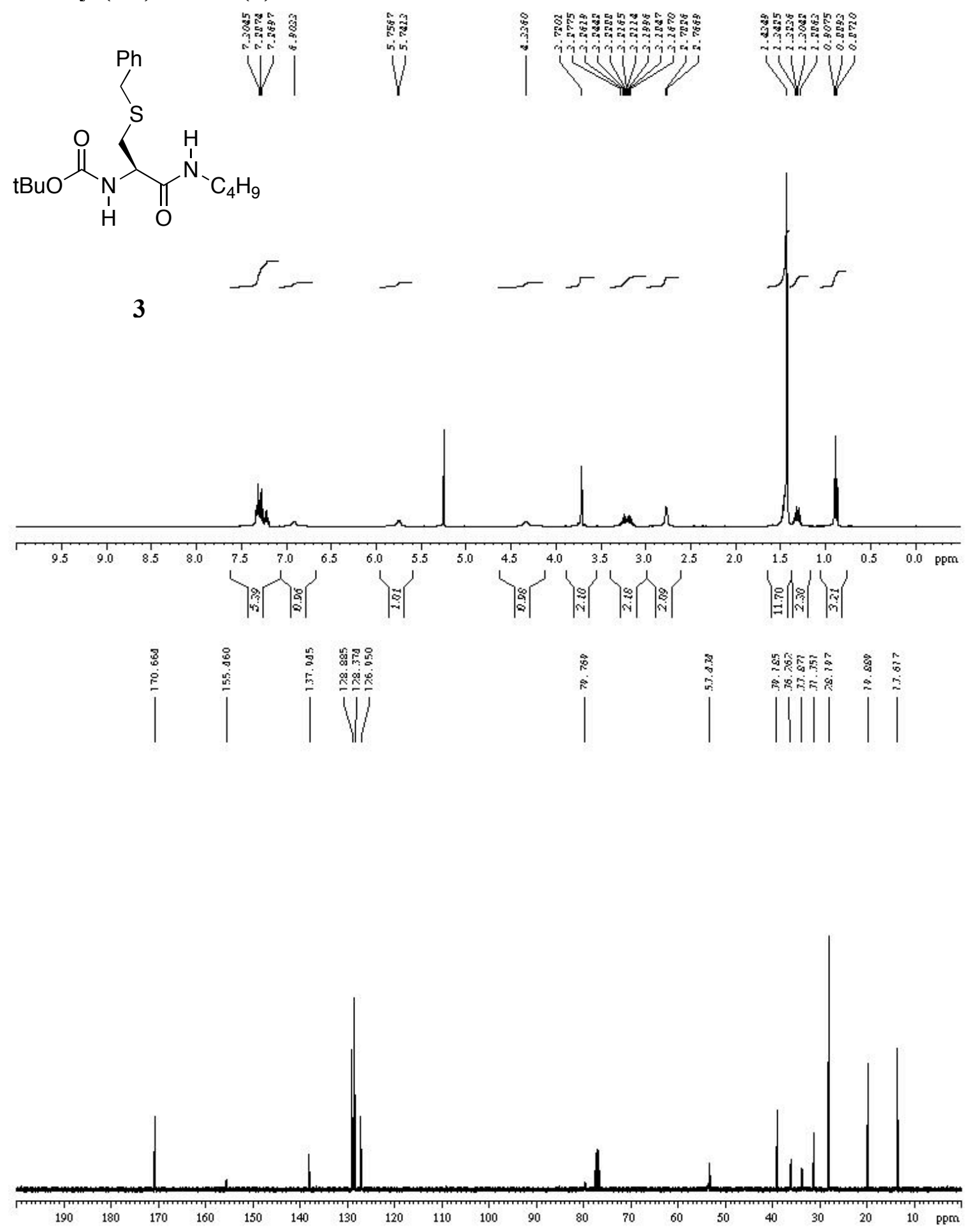


\section{Ac-Cys(Bn)-NHBu (4)}

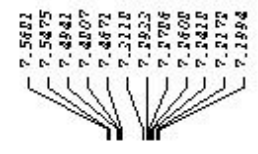

ㅇํㄹㄷㅗำ

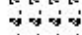

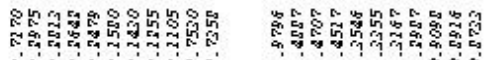

(1)

(1)

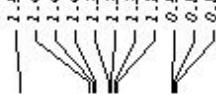

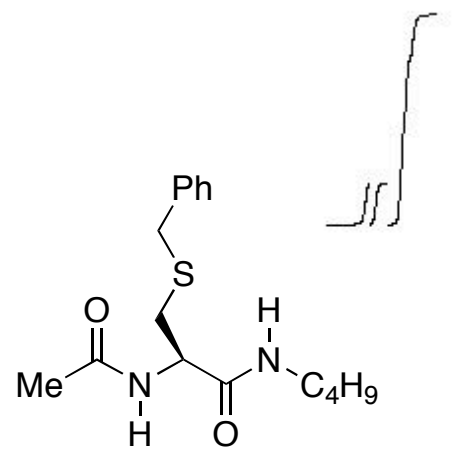
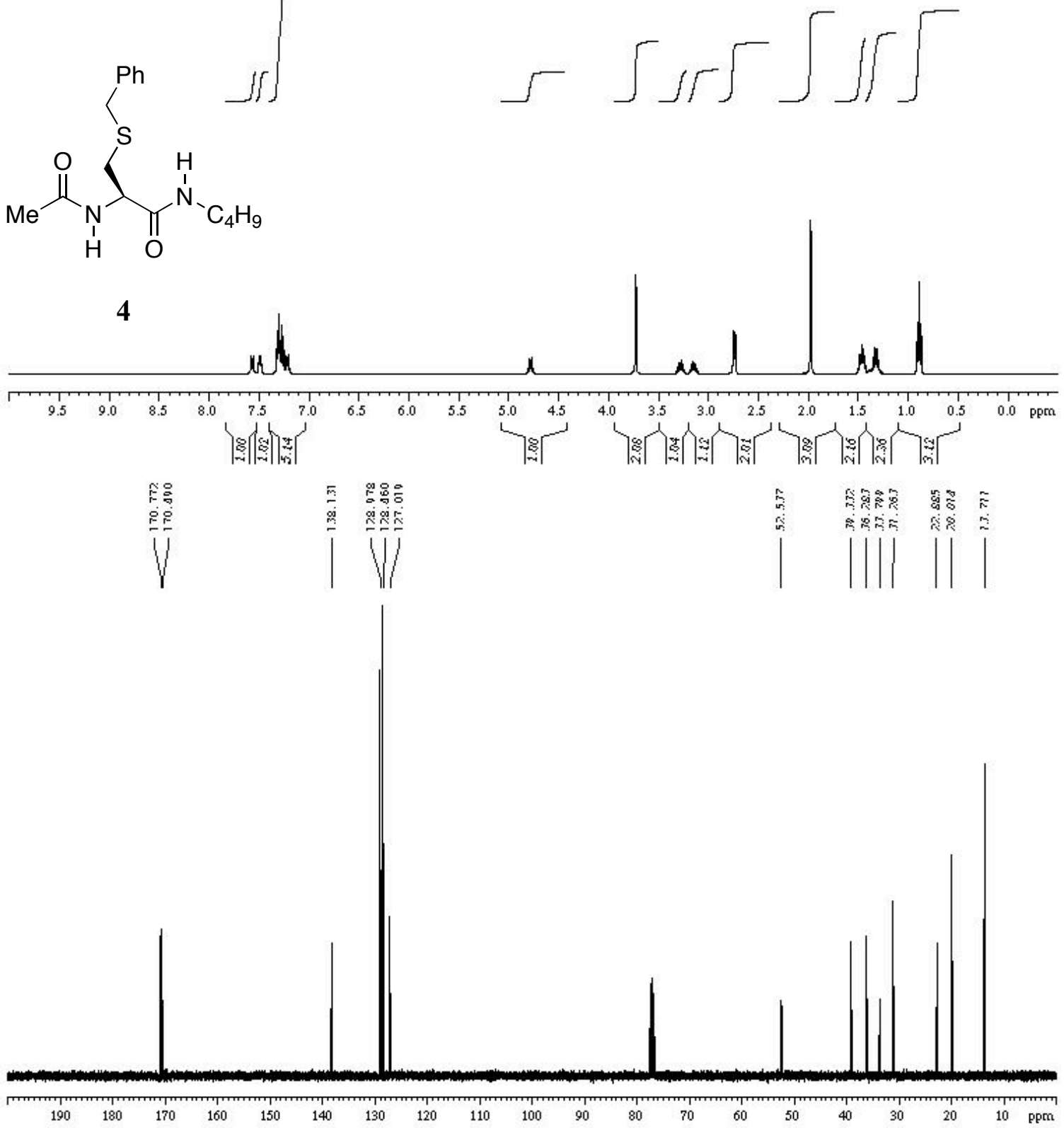


\section{Boc-Leu-NMe $(9)$}
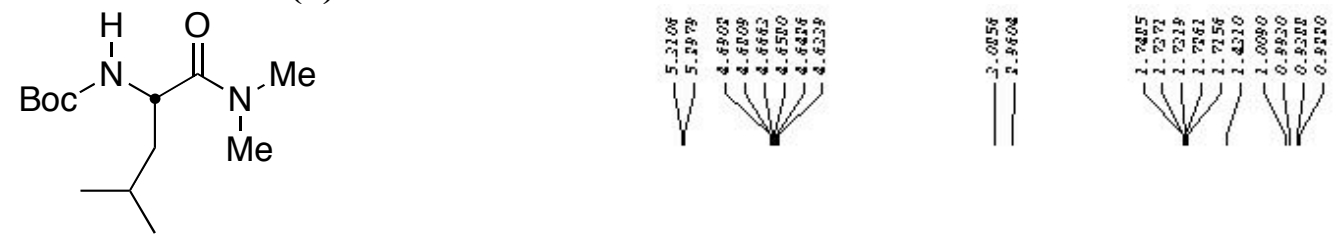

9
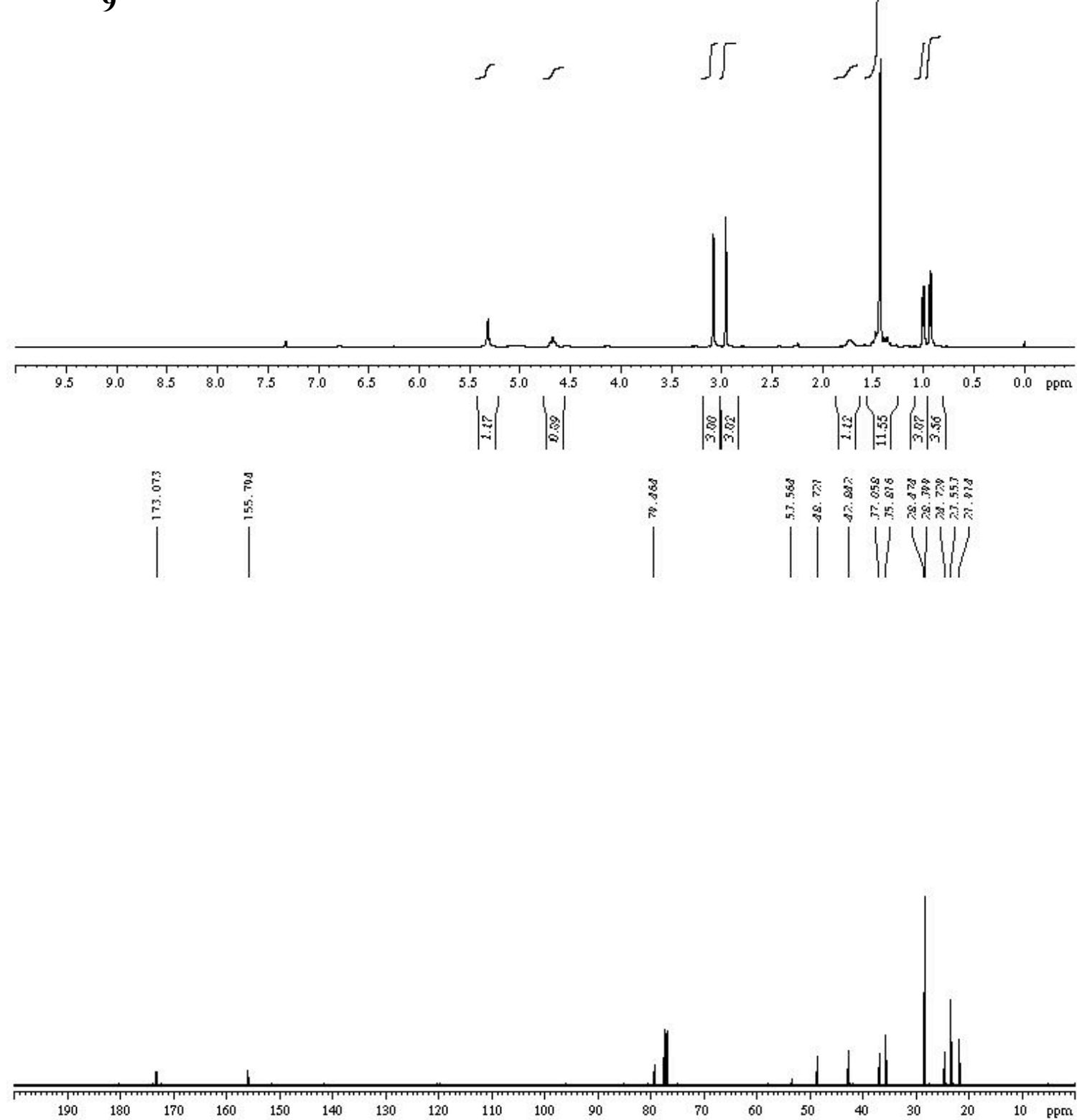


\section{Fmoc-Cys(Trt)-Leu-NMe 2 (10)}

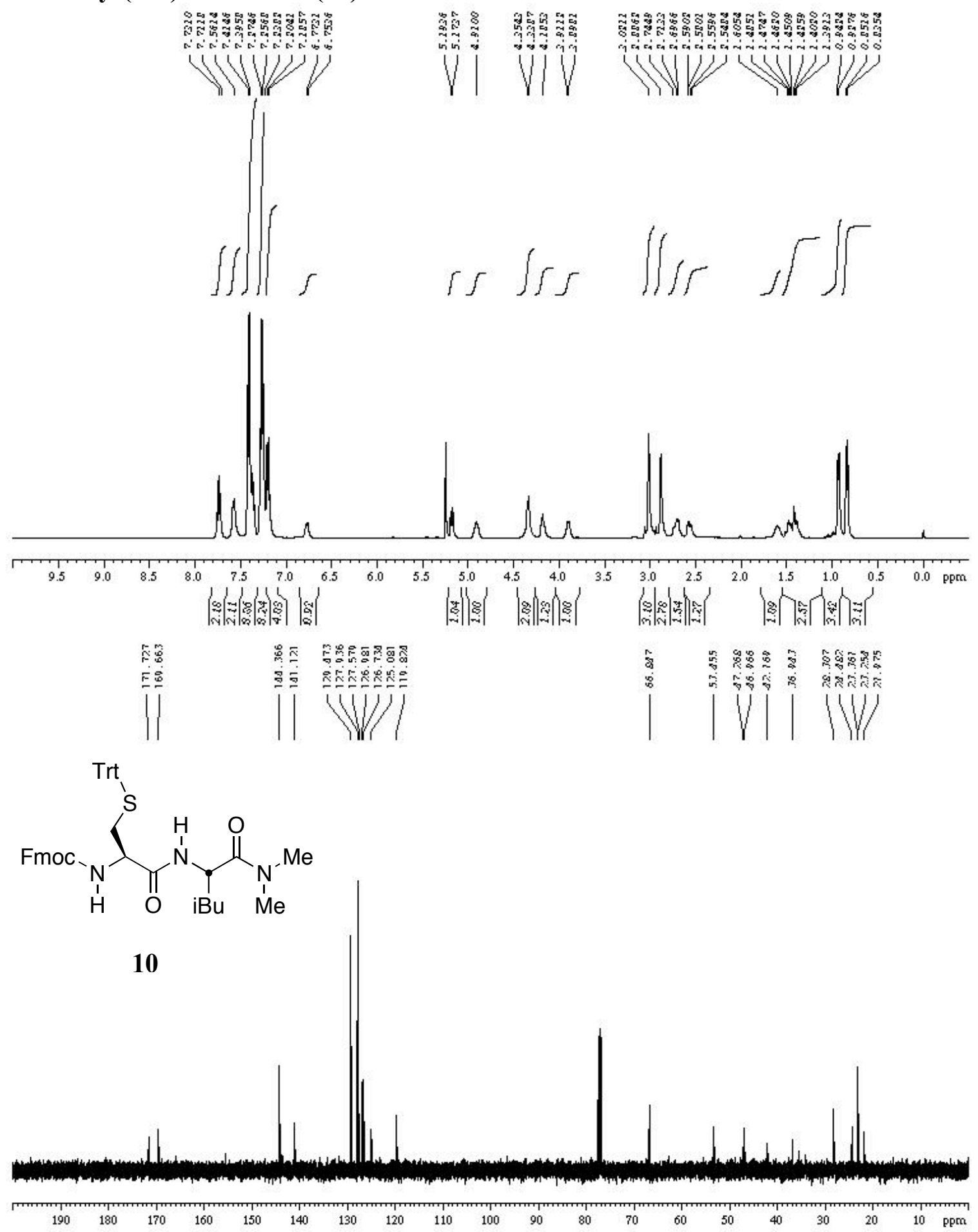




\section{Oct-Ala-OBn (11)}
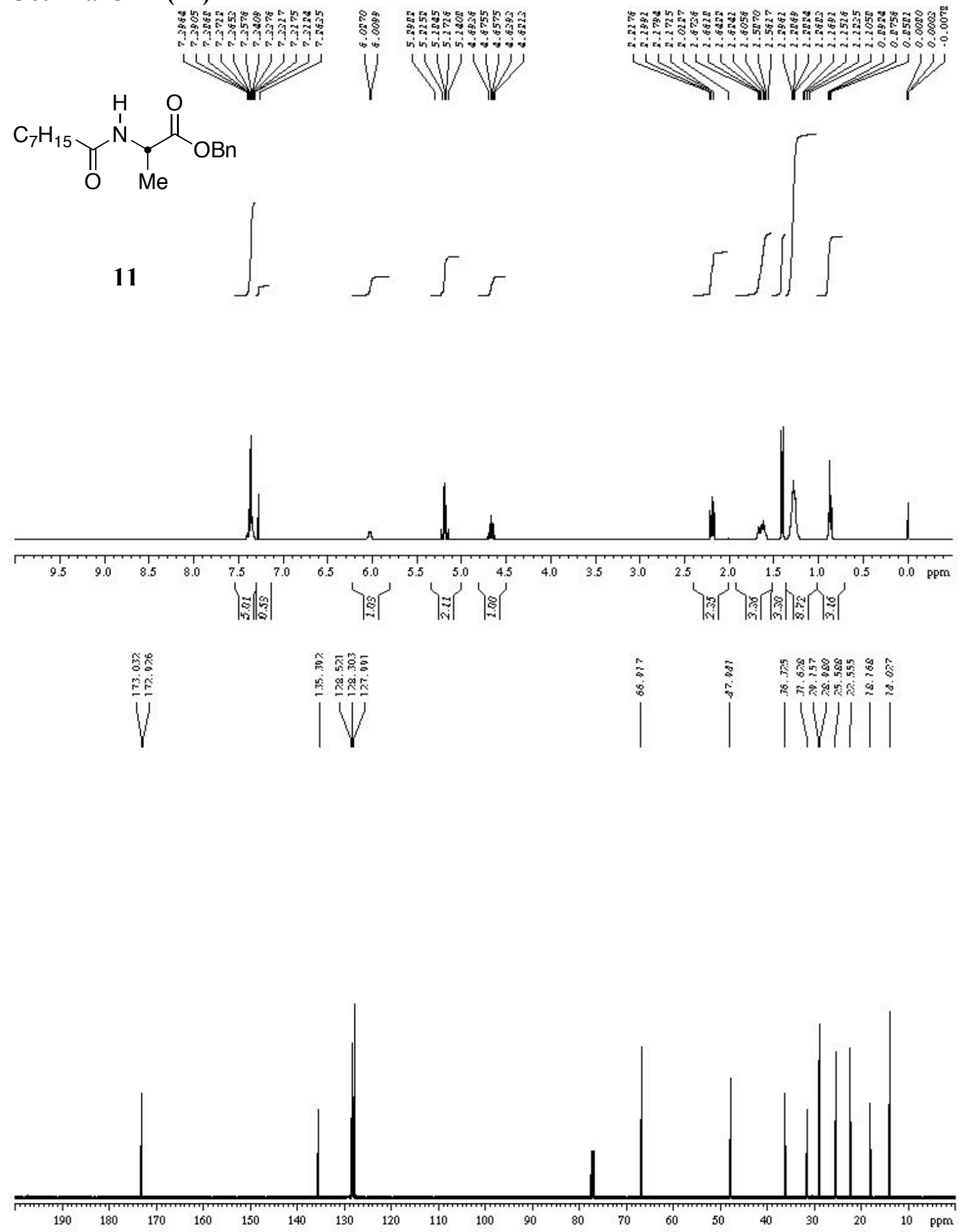
Oct-Ala-Cys(Trt)-Leu-NMe 2 (7)
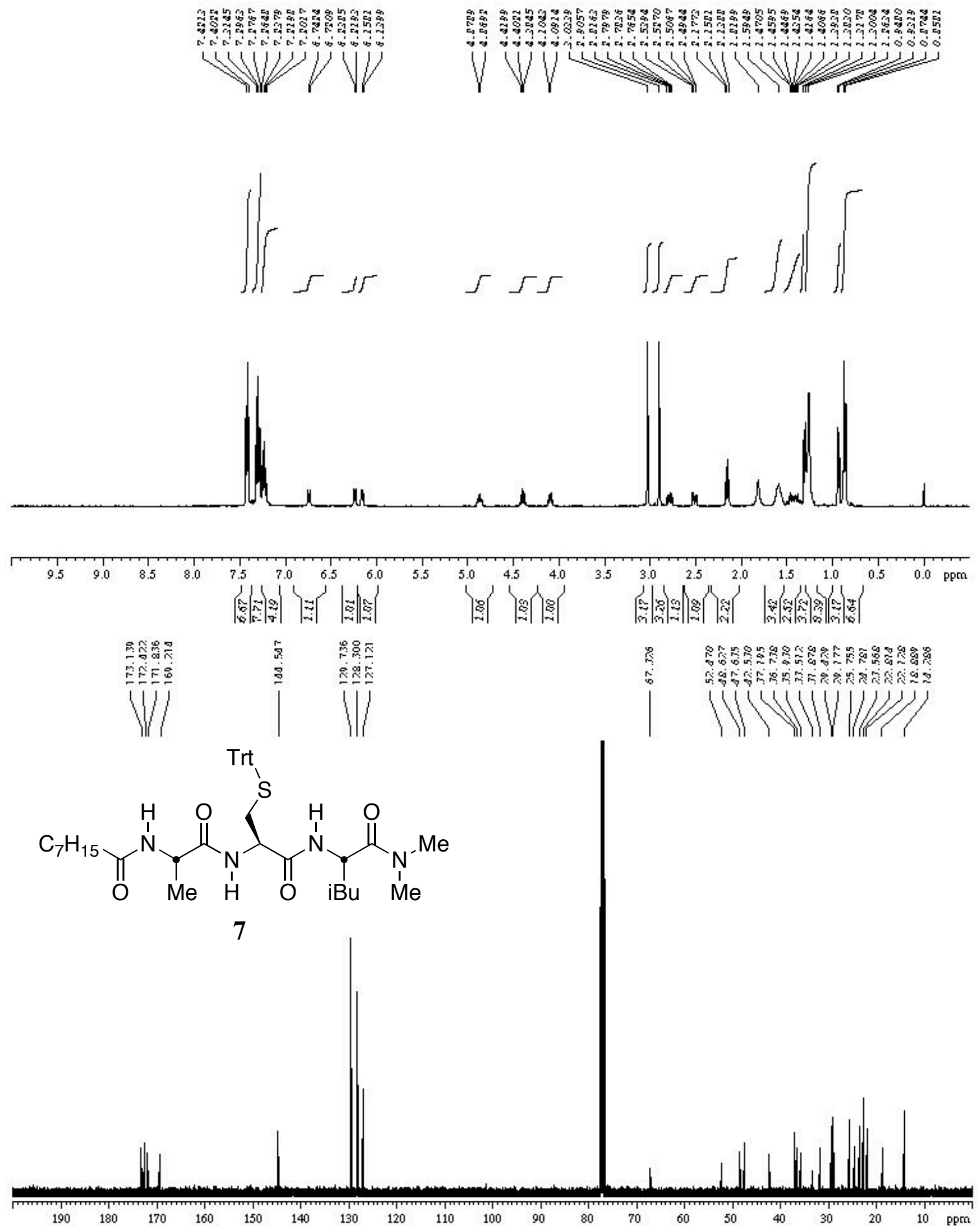
COSY spectra for Oct-Ala-Cys(Trt)-Leu-NMe 2 (7)

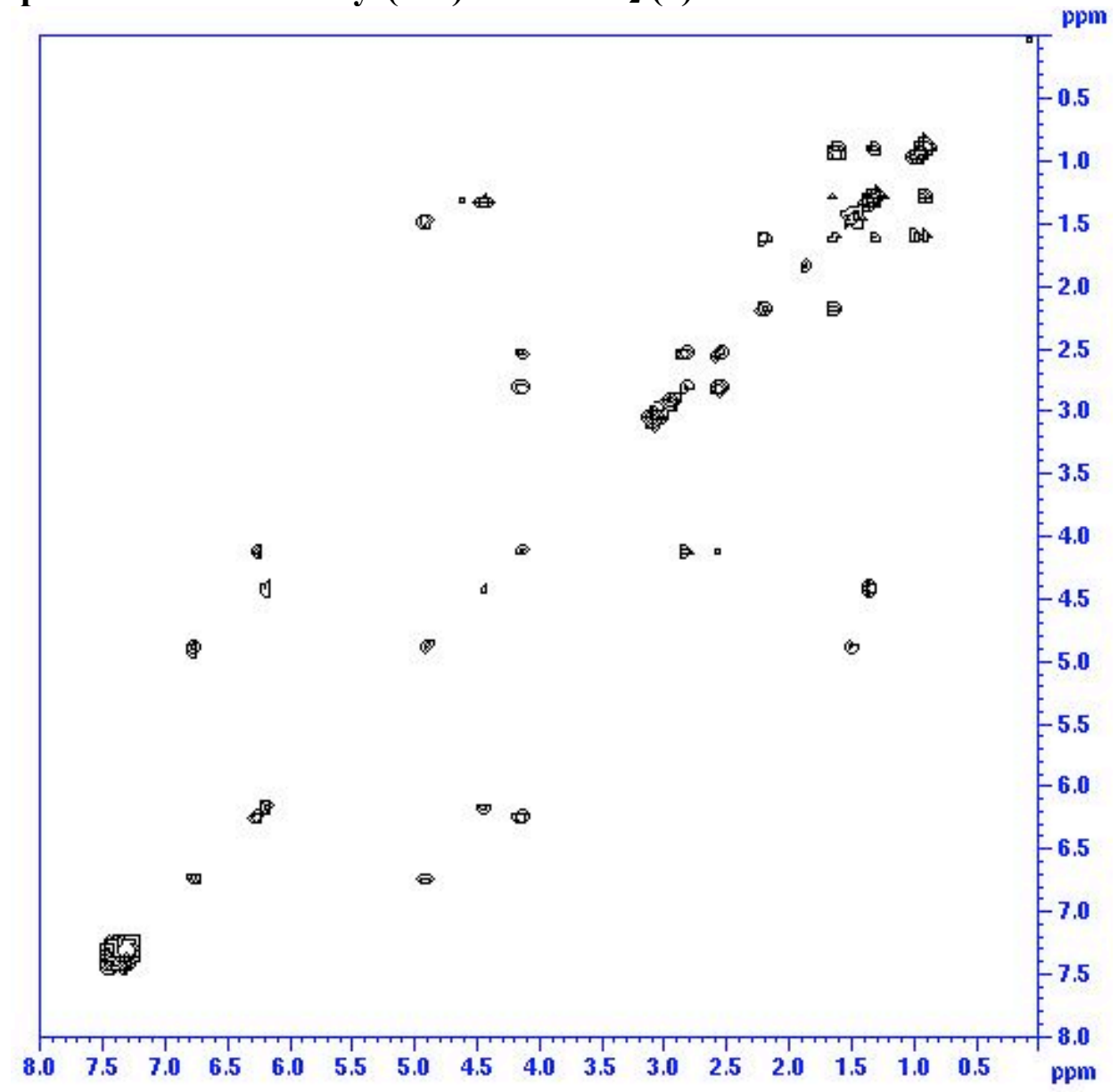


(Oct-Ala-Cys-Leu-NMe $)_{2}$ (8)

$\sqrt{n}$
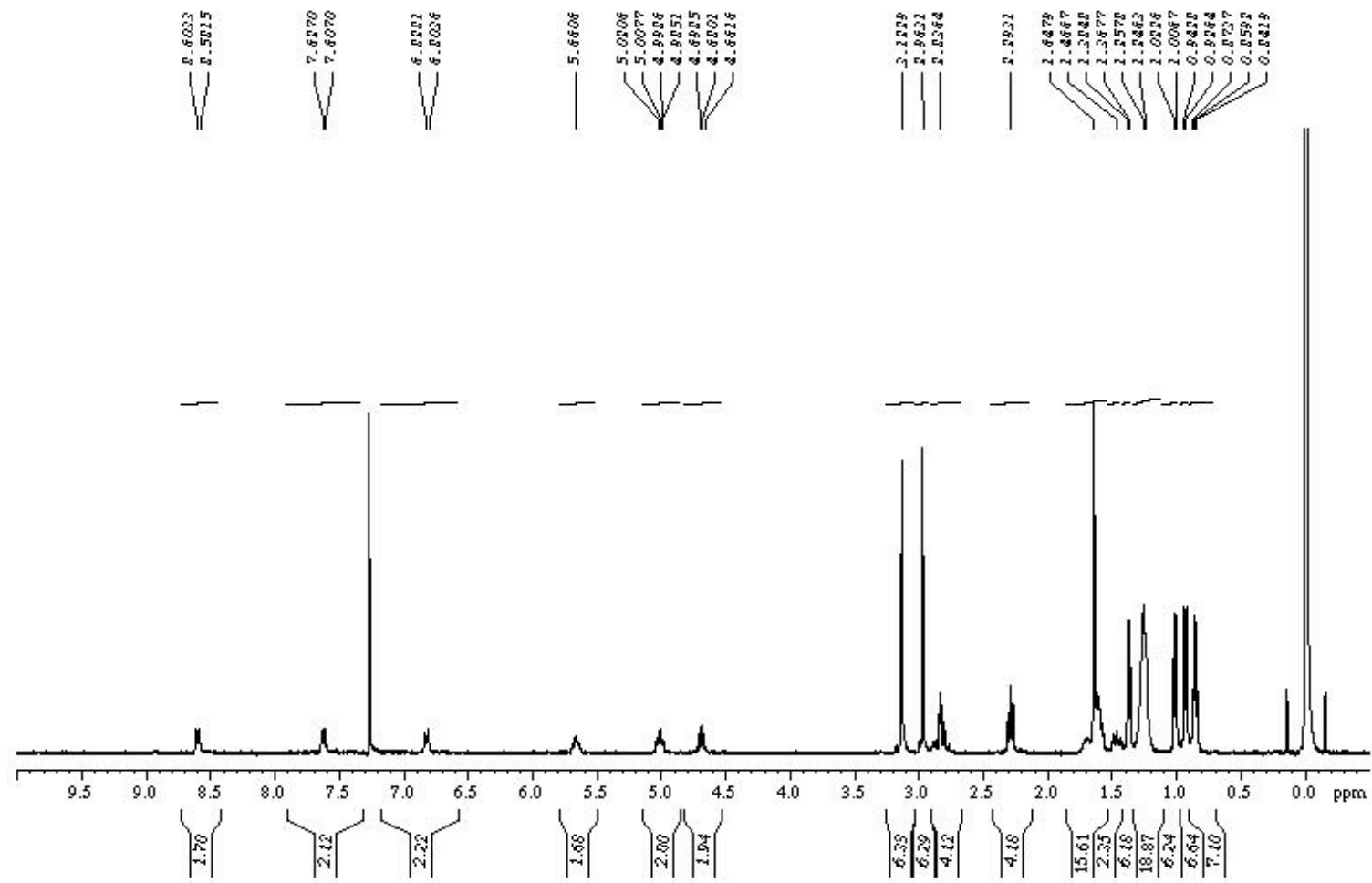

11

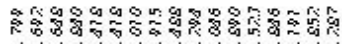

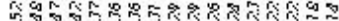

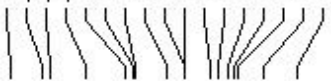

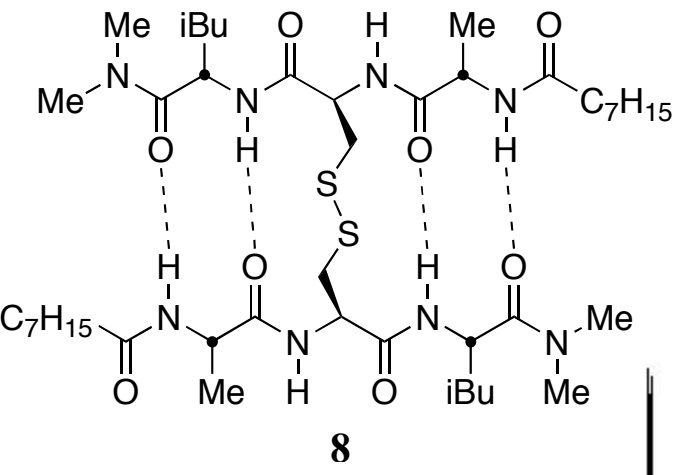

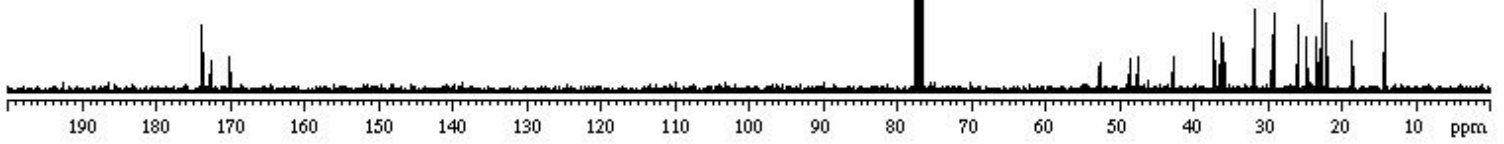


COSY spectra for (Oct-Ala-Cys-Leu-NMe $)_{2}(8)$

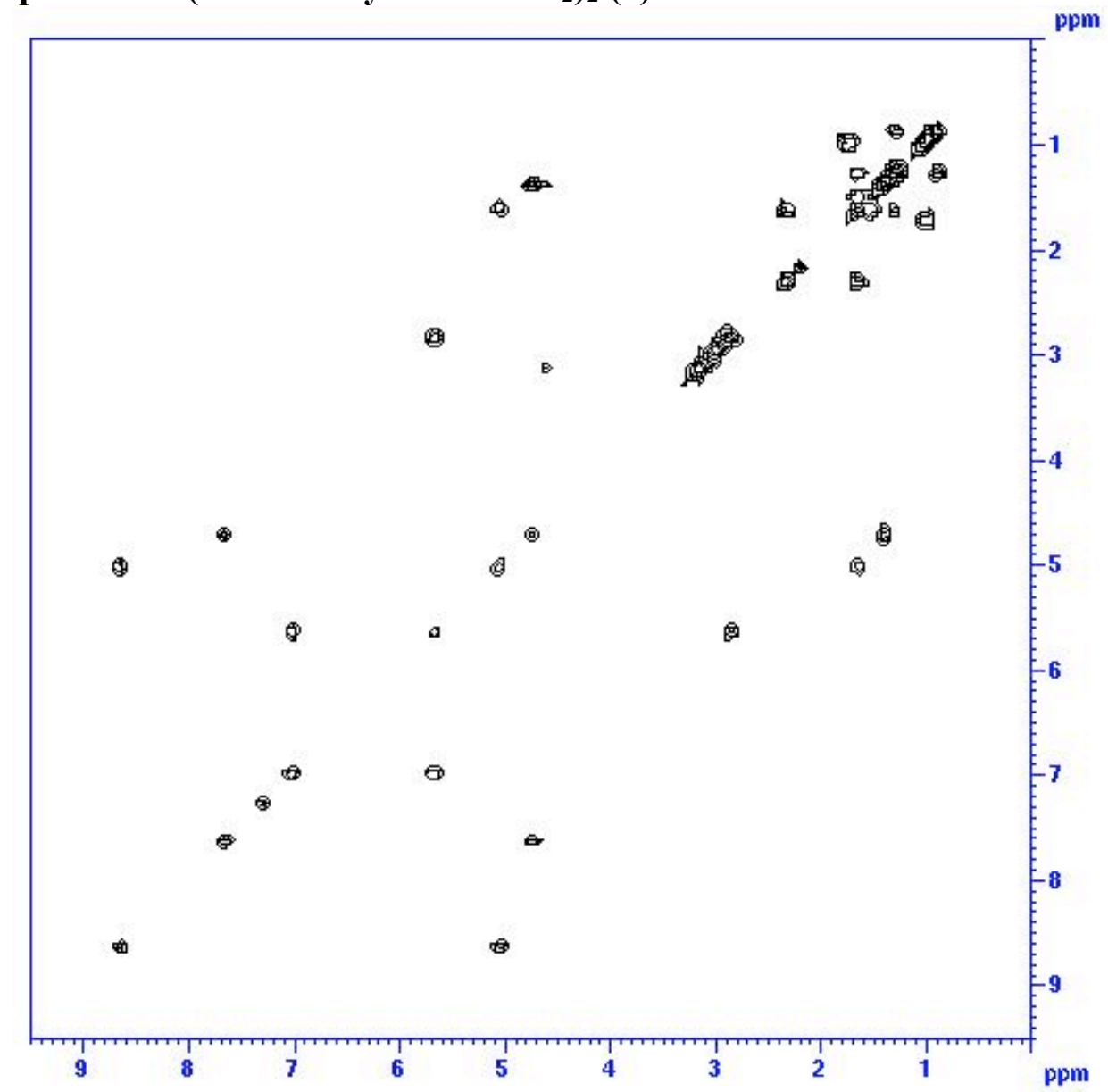


NOESY spectra (300 $\mu$ s mixing time) for (Oct-Ala-Cys-Leu-NMe $)_{2}(8)$

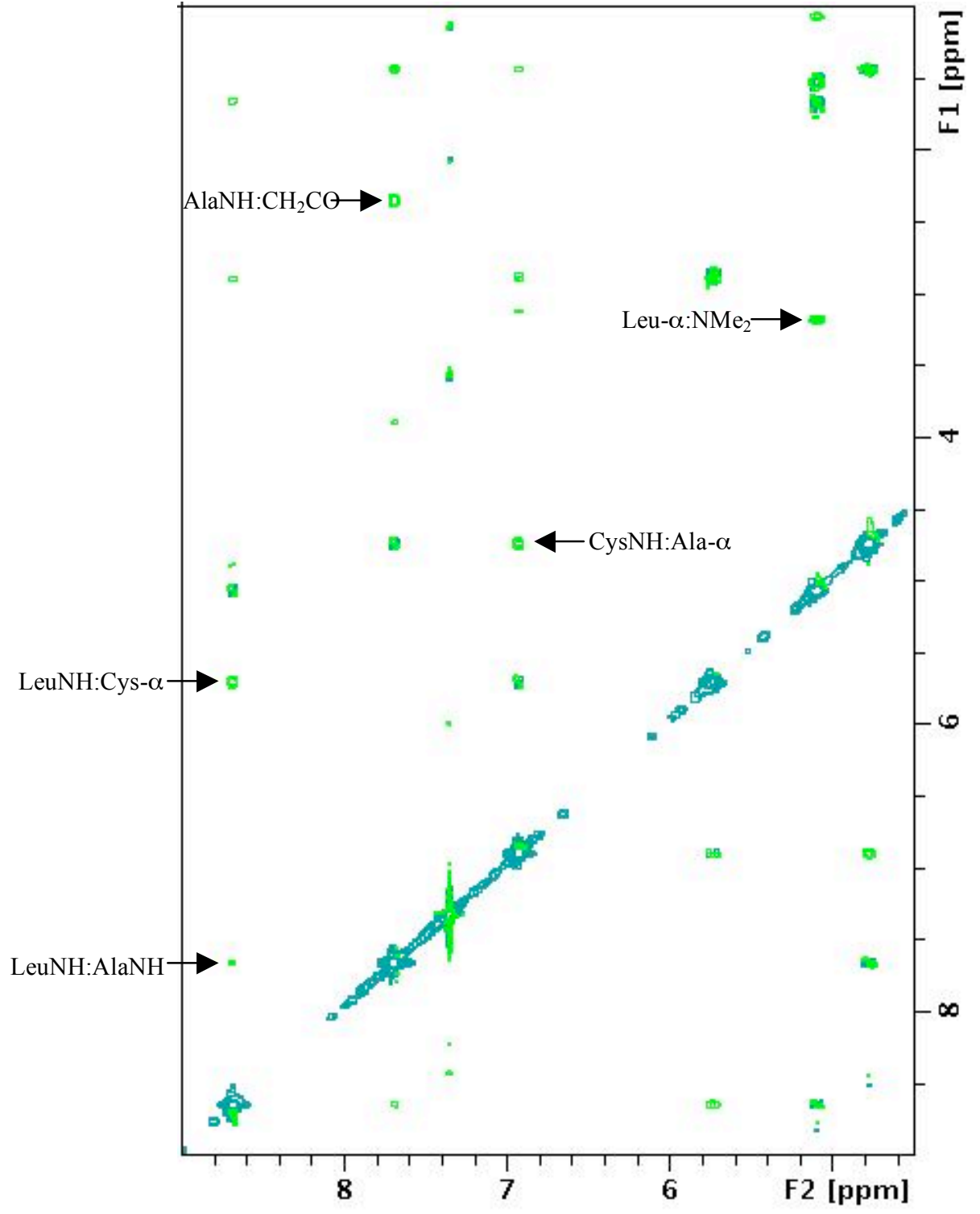

